\title{
Development of a comet-FISH assay for the detection of DNA damage in hemocytes of Crassostrea gigas
}

\author{
Pérez-García C. ${ }^{1,}{ }^{*}$, Rouxel Julien ${ }^{1}$, Akcha Farida ${ }^{1}$ \\ ${ }^{1}$ Ifremer, Department of Biogeochemistry and Ecotoxicology, Laboratory of Ecotoxicology, Rue de l'lle \\ d'Yeu, BP 21105, 44311 Nantes Cedex 03, France \\ * Corresponding author : C. Pérez-García, Tel.: +33 240374142 ; email address : mcperezg@ifremer.fr
}

\begin{abstract}
:
In this work, the DNA-damaging effect of hydrogen peroxide on the structural integrity of nucleolar organizer regions (NORs) was studied for the first time by comet-FISH in the Pacific oyster Crassostrea gigas. Global DNA damage was assessed in hemocytes using an alkaline version of the comet assay. Next, NOR sensitivity was analysed by mapping major rDNA repeat unit by fluorescence in situ hybridisation (FISH) on the same comet slides. Exposure of hemocytes to $100 \mu \mathrm{M}$ of hydrogen peroxide induced a significant increase in both DNA damage and number of FISH-signals of major ribosomal genes versus the control. Moreover, a significant positive correlation was shown between DNA damage as measured by the comet assay (percentage of DNA in comet tail) and the number of signals present in comet tails. This study demonstrates the potential value of the comet-FISH assay for the study of DNA damage induced by genotoxicant exposure of target genes. It offers a perspective for better understanding the impact of genotoxicity on animal physiology and fitness.
\end{abstract}

\section{Highlights}

- A Comet-FISH assay has been developed in hemocytes of Crassostrea gigas. Hydrogen peroxide causes fragmentation of nucleolar organizer regions. The sensitivity of genome region to genotoxicant exposure could be analyzed using comet-FISH.

Keywords : Crassostrea gigas, hydrogen peroxide, comet assay, comet-FISH, genotoxicity 


\section{Introduction}

Pollutant levels in the marine environment have increased in recent years due to anthropogenic activities. Urban sewage and industrial, mining and agricultural waste arrive in the sea through controlled and accidental discharges and runoff waters. These effluents can contain compounds with genotoxic effects, potentially inducing DNA structural lesions such as oxidation of nucleotide bases, formation of DNA adducts and abasic sites and breakage of single or double DNA strands. Genome integrity is preserved by cell DNA repair systems. However, in case of extensive DNA damage, an apoptotic response can be induced in the cells, preventing a tumorogenesis process (Roos and Kaina, 2013). System failure may entail the appearance of mutations and chromosome arrangements, with disastrous consequences for the cell (Magnander and Elmroth, 2012; Mermershtain and Glover, 2013). Indeed, the resulting physiological and pathological changes in cells and tissue may affect the individual's fitness and survival. DNA damage can also affect the germline, hence decreasing fertility and enabling mutations and chromosomal rearrangements, which may be handed down to subsequent generations. Sperm DNA fragmentation can be responsible for both a decrease in fertility and embryonic development defects (Derijck et al., 2007; González-Marín et al., 2012; Santos et al., 2013; Simoes et al., 2013).

Various techniques are available for the study of DNA damage (as reviewed by Dixon et al., 2002). Among these, the comet assay is a versatile, sensitive and rapid method, allowing DNA damage to be measured inexpensively (Collins, 2004). In this assay, cells embedded in agarose gels on microscope slides are subjected to an electric field after being lysed with detergents and high ionic strength. For the purpose of lysis treatment, histones, cells and nuclear envelopes are removed, preserving only the attachments between negative supercoiled DNA molecules and the nuclear matrix. As a result, the loops of DNA molecules attached to the nuclear matrix form a compact structure called nucleoids (Cook and Brazell, 1976). If a breakage occurs on a single or both DNA strands, the loop loses its supercoiling and achieves a more relaxed state. In the presence of an electrophoresis field, the relaxed DNA loops of nucleoids migrate from the nucleus towards the anode, forming a comet tail (Afanasieva et al., 2010; Shaposhnikov et al., 2008). The percentage of DNA present in the tail correlates with the degree of DNA strand breakage. According to comet assay test conditions, alkali labile sites, single and double strand breaks can be detected. In alkaline conditions ( $\mathrm{pH}>13)$, DNA denaturation occurs and the comet tail is the result of all three types of DNA lesions. Conversely, if the comet assay is conducted in neutral conditions, the comet tail is composed 
of double strand DNA and only double strand breaks are detectable (Shaposhnikov et al., 2008). However, despite its numerous advantages, the comet assay alone does not allow the identification of genome sequences affected by DNA alterations. A sequence of interest can be specifically detected on comets by fluorescence in situ hybridisation (FISH) using a labelled probe. The combination of both methods allows analysis of the structural integrity of a specific gene or chromosomal region.

Despite the achievements obtained recently by the comet-FISH in the analysis of gene and chromosomal sensitivity (Mladinic et al., 2012; Reiter et al., 2012; Volpato et al., 2008, Hovhannisyan et al., 2005) this method had not been applied to date in bivalves in the framework of ecotoxicological studies. Their wide geographical distribution, filter feeding, sessile lifestyle and ability to bioaccumulate pollutants make the bivalves valuable sentinels of aquatic ecosystems life (López-Barea and Pueyo, 1998; Waykar and Deshmukh, 2012). Crassostrea gigas possesses all of these characteristics and has been widely studied from a biological, physiological and ecological perspective (Bachère et al., 2004; Robert and Gerard, 1999; Samain, 2011). This bivalve is also of major, worldwide economic interest, particularly in France, where it is one of the most extensively-farmed shellfish species (FAO, 2012).

This article describes the first application of the comet-FISH technique for the detection and quantification of DNA damage in bivalves by analyzing the structural integrity of nucleolar organizer regions (NORs) further to hydrogen peroxide exposure. Hydrogen peroxide is a model direct genotoxicant, causing DNA lesions through the oxidation of purine and pyrimidine bases, the formation of strand DNA breaks, abasic sites and DNA protein crosslinks (Asad et al., 2004).

NORs are the chromosomal regions in which tandem repeated DNA sequence encoding for 18S-5.8S-28S rRNA genes are located. At the end of the telophase, when rDNA transcription is reactivated, the nucleoli assemble around the rDNA clusters (Hernandez-Verdun, 2006). Transcription, processing of major ribosomal genes and assemblage of ribosomal subunits take place within the nucleoli. Therefore, major rDNA instability may reduce transcription, leading to a reduction in ribosome biosynthesis and cell malfunctions (Kobayashi, 2008). The comet assay was performed in alkali conditions in order to estimate overall DNA damage. NORs were detected on comet slides by FISH using two plasmids containing the major rDNA repeat unit as a probe. The number and distribution of signals corresponding to major rDNA genes in the comets were registered and analysed. 


\section{Material and Methods}

\subsection{Chemical reagents}

$\mathrm{Na}_{2} \mathrm{HPO}_{4}, \mathrm{NaH}_{2} \mathrm{PO}_{4}$, hydrogen peroxide, colchicine, $\mathrm{KCl}, \mathrm{KH}_{2} \mathrm{PO}_{4}$, normal and low melting point agarose, ethylenediaminetetraacetic acid (EDTA), $\mathrm{Na}_{2}$ EDTA, Trizma base, sodium lauroyl sarcosinate, dimethyl sulfoxide (DMSO), triton $\mathrm{X}-100, \mathrm{NaOH}$, , tris $\mathrm{HCl}$, cetyl trimethyl ammonium bromide (CTAB), polyvinyl-pyrrolidone PV40, B-mercaptoethanol, chloroform: isoamyl alcohol solution (24:1), dextran sulphate, 4-(2-Hydroxyethyl)piperazine1-ethanesulfonic acid (HEPES), sodium acetate and ammonium acetate were purchased from Sigma Aldrich. Sybr Green and propidium iodide were acquired from Life Technologies. Acetic acid, formamide and albumin fraction $\mathrm{V}$ were from Merck. Fluorescein avidin, biotinylated antiavidin antibody and vectashield were purchased from Vector. Formamide deionized and glycogen were from Ambion. Ethanol and $\mathrm{NaCl}$ were, respectively, from Fluka and Biosolve. The nick translation system was from Invitrogen. Biotin-11-dUTP was from Thermo Scientific, Tween 20 from Acros and sodium citrate from Prolabo. To amplify DNA probes, GeneAmp PCR Reagent Kit with AmpliTaq DNA Polymerase from Applied Biosystems was used. Ultra-pure deionized water was prepared using a Milli-Q system (Millipore, Molsheim, France).

\subsection{Animals}

The hemolymph $(0.5 \mathrm{~mL})$ of 15 adult of Crassostrea gigas $(2 \mathrm{n}=20)$ was taken from the adductor muscle using a syringe with a 21-22 $\mathrm{G}$ needle and filled with $0.2 \mathrm{~mL}$ of an antiaggregant solution (AASH). The hemolymph from all the individuals was pooled, filtered using a $30 \mu \mathrm{m}$ mesh (Parterc cell trics) and dispatched to constitute 6 sub-samples. Three were used as controls and the other three were exposed to $100 \mu \mathrm{M}$ of hydrogen peroxide for 1 $\mathrm{h}$ at room temperature in the dark.

Hemocyte viability was assessed before and after exposure to hydrogen peroxide by flow cytometry (BD accuri C6). Fresh samples were stained using SYBR Green I (10X final) and propidium iodide $(10 \mu \mathrm{g} / \mathrm{mL})$ as described by Dang et al. (2011). In order to estimate the amount of DNA per cell, a portion of each hemocyte sample was also fixed with ethanol, then stained with propidium iodide $(50 \mu \mathrm{g} / \mathrm{mL}$, prepared in Calcium-magnesium-free saline buffer 
with $0.5 \%$ Tween 20 and $1 \mathrm{mg} / \mathrm{mL}$ boiled RNAse) for $45 \mathrm{~min}$ at room temperature in the dark. In both assays, three measurements were performed per sample and an average of 10,000 cells was counted on each round.

\subsection{Alkaline Comet Assay}

The alkaline comet assay was performed in alkaline conditions according to Akcha et al. (2003). Slides previously coated with $0.5 \%$ normal melting point agarose in $\mathrm{Ca}^{2+}$ and $\mathrm{Mg}^{2+}$ free 1X PBS were covered with $85 \mu \mathrm{L}$ of hemocyte suspension prepared in $0.5 \%$ low melting point agarose (in $\mathrm{Ca}^{2+}$ and $\mathrm{Mg}^{2+}$ free $1 \mathrm{X}$ PBS) and covered with a cover slip. The slides were placed on a cold metal plate at $4^{\circ} \mathrm{C}$ for $5 \mathrm{~min}$ in order to solidify the agarose. The cover slips were then withdrawn and $90 \mu \mathrm{L}$ of low melting point agarose $(0.5 \%$ in $1 \mathrm{X}$ PBS) was deposited on the slides and scattered with a cover slip for the last gel layer.

To lyse cell and nuclear membranes, the slides were immersed in a glacial lysis buffer $(\mathrm{NaCl}$ $2.5 \mathrm{M}, \mathrm{Na}_{2}$ EDTA $0.1 \mathrm{M}$, Trizma base $0.01 \mathrm{M}$, sodium lauroyl sarcosinate $1 \%$, DMSO 10\%, Triton $\mathrm{X}-1001 \%, \mathrm{pH} 10.0$ ) for $1 \mathrm{~h}$ at room temperature in the dark. Next, the slides were placed in a horizontal electrophoresis chamber containing a freshly-prepared electrophoresis buffer ( $\mathrm{NaOH} 0.3 \mathrm{M}$, EDTA $0.001 \mathrm{M}, \mathrm{pH} 13.0)$, where they were left for $15 \mathrm{~min}$ at $20^{\circ} \mathrm{C}$ to allow DNA unwinding. DNA migration was performed in this buffer for 20 min at $23 \mathrm{~V}$ (390 $\mathrm{mA}, 0.66 \mathrm{~V} / \mathrm{cm})$. The slides were then washed in Tris base $0.4 \mathrm{M}, \mathrm{pH} 7.5$ for $2 \times 5 \mathrm{~min}$ at room temperature, dehydrated in increasing ethanol series $(70 \%, 90 \%$ and $100 \%)$ and airdried. Two slides were prepared for each replicate $(n=3)$ from both the control and exposed group.

\subsection{Mitotic chromosome and nuclei spreads}

In order to demonstrate that the probe for major ribosomal genes hybridise only in their corresponding locations, mitotic chromosome and nuclei spreads were performed. Chromosome and nuclei preparations were obtained from gills according to the method described by Martínez-Expósito et al. (1994). After exposing the specimens to colchicine $(0.005 \%)$ for $12 \mathrm{~h}$, the gills were excised, rinsed and fixed with a mixture of ethanol/acetic acid in three baths of 20 min each. To obtain chromosome and nuclei spreads, small pieces of fixed gills were dissociated in $60 \%$ acetic acid and the cell suspension was dropped onto 
slides heated to $55^{\circ} \mathrm{C}$.

\subsection{Fluorescence in situ hybridisation (FISH)}

Major ribosomal genes were produced in high quantities using the plasmids HM123 and HM 456, containing the major ribosomal gene repeat unit (18-5.8-28S) from Xenopus laevis (Meunier-Rotival et al., 1979). The probe was labelled with biotin-11-dUTP (Thermo Scientific) for $1 \mathrm{~h} 30 \mathrm{~min}$ at $15{ }^{\circ} \mathrm{C}$ using the Nick translation system (Invitrogen) in accordance with the manufacturer's instructions. Hybridisation on interphase nuclei and chromosome spreads was performed to check proper probe functioning.

The comet slides prepared as described above were denatured in $0.5 \mathrm{~N} \mathrm{NaOH}$ for 30 min at room temperature. The gels were then neutralized in $1 \mathrm{X}$ PBS $\mathrm{pH} 7.4$ for $1 \mathrm{~min}$ at room temperature. The chromosome spreads were denatured in a solution of $70 \%$ formamide in $2 \mathrm{X}$ SSC (0.3 M NaCl, $0.03 \mathrm{M}$ tri-sodium citrate dihydrate) for $2 \mathrm{~min}$ at $69{ }^{\circ} \mathrm{C}$. Once denatured, the comet and chromosome slides were dehydrated in an increasing ethanol series $(70,90$, 100\%, $3 \mathrm{~min}$ each) and air-dried. The hybridisation mixture, containing $30 \mathrm{ng} / \mu \mathrm{L}$ of labelled DNA and a 1:1 ratio of formamide deionized and 20\% dextran sulphate in 8X SSC, was denatured at $80{ }^{\circ} \mathrm{C}$ for $8 \mathrm{~min}$. Once denatured, $20 \mu \mathrm{L}$ of the hybridisation mixture was added to each slide, covered with a cover slip and incubated overnight at $36.5{ }^{\circ} \mathrm{C}$ in a humidified chamber.

Stringency washes were done in agitation using a solution of $50 \%$ formamide prepared in $2 \mathrm{X}$ SSC and 0.1X SSC for $3 \times 5$ min each at room temperature. Blocking was performed at $35^{\circ} \mathrm{C}$ for $30 \mathrm{~min}$ using $5 \%$ bovine albumin solution prepared in $4 \mathrm{X} \mathrm{SSC} / 0.2 \%$ Tween 20 . The biotin-labelled probe was detected using fluorescein avidin and biotinilated antiavidin antibodies (Vector). The slides were stained with propidium iodide $(0.07 \mu \mathrm{g} / \mathrm{mL})$ in $2 \mathrm{xSSC}$ for $8 \mathrm{~min}$ and, once washed and dried, mounted with Vectashield medium (Vector). All experiments were carried out in dark conditions to prevent additional DNA damage by natural light.

The preparations were examined with an Olympus BX60 fluorescence microscope using the proper filter set (U-MWG and FITC 31001 from Olympus). Images for each filter were captured with an Andor camera DL-658M and merged using Gimp. The number of signals 
and their localization in both the comet head and tail were recorded for each nucleoid. DNA damage on each comet picture was analysed using the Komet Version 5.1 image analyses system (Kinetic Imaging, Liverpool, UK). The percentage of tail DNA (TD) was the comet parameter selected to quantify global DNA damage.

Forty randomly-selected nuclei with FISH signals were analysed on each slide. The FISHsignals were classified in two classes: dots and clouds of dots. Dot signals were defined as circle shaped signals or those smaller than $0.6 \mu \mathrm{m}$ in the major axis. Clouds of dots were characterized by the superposition of dots or by several dots closed by a distance lower than $1.5 \mu \mathrm{m}$. A cloud of dots was scored as a single unit, since they represent a cluster of tandem repeated rDNA transcriptional units. A total of 240 nuclei were then analysed per group. Nuclei presenting hedgehog comets and comets without FISH signals were excluded from the comet analysis.

The data was analysed using Statistica software 6.0 (Statsoft). The mean values of TD were normalized using its square root and analysed by an ANOVA. The effect of hydrogen peroxide exposure on the number of signals detected by FISH for major rDNA genes was analysed using a Mann-Whitney $U$ test. The correlation between $\sqrt{ } \mathrm{TD}$ and the number of signals was studied using Spearman's correlation coefficient.

\section{Results}

\subsection{Cell Viability and cell cycle}

The cell viability of both the control and exposed samples was higher than $97 \%$ (Mean $=$ $97.67 \pm 0.11)$, indicating appropriate conditions for application of the comet assay. No significant differences were found between cells exposed to hydrogen peroxide and controls (Mann-Whitney U, p > 0.01). Hydrogen peroxide showed no cytotoxicity following $1 \mathrm{~h}$ exposure to $100 \mu \mathrm{M}$ versus controls (Wilcoxon test, $\mathrm{p}>0.01$ ).

Genome size was similar in both groups. The percentage of $2 \mathrm{C}$ and $4 \mathrm{C}$ cells was $88.23 \%$ and $4.6 \%$, respectively in the control and exposed groups (Fig 1). The 2C peak corresponded to $\mathrm{G}_{\mathrm{o}} / \mathrm{G}_{1}$ population, whereas the $4 \mathrm{C}$ peak was interpreted as $\mathrm{G}_{2} / \mathrm{M}$ or polyploid cells. 


\subsection{Comet-FISH}

After $1 \mathrm{~h}$ exposure to $100 \mu \mathrm{M}$ of hydrogen peroxide, a significant increase in DNA damage as measured by comet TD was detected in the hemocytes of Crassostrea gigas after applying a one-way ANOVA (random model, nested design) ( $\mathrm{p}<0.001$, Fig 2a). No significant differences were found between replicates in either experimental group, indicating homogenous exposure conditions.

Fluorescence in situ hybridisation experiments on mitotic chromosome and nucleus spreads showed a unique site of hybridization of the probe corresponding to the NORs location, i. e. the terminal region of the long arms of the metacentric chromosome pair 10 (Insua and Thiriot-Quiévreux, 1992 and Xu et al., 2001, Fig 3a), demonstrating the proper probe functioning. Comet-FISH experiments revealed major rDNA FISH-signals to appear as both individual dots and clouds of dots dispersed over the comets. Dot clouds were more frequent in comet heads, whereas individual signals were more frequently observed in comet tails (Fig 3b-i). No dot chains were observed in comet tails. The number of signals ranged from 1 to 4 in little-damaged nucleoids (Fig 3b-d) and from 1 to 32 in nucleoids with a comet tail (Fig 3ei). Moreover, in cells exposed to hydrogen peroxide, nucleoids without a comet tail also exhibited 1 to 4 signals, similarly to undamaged nucleoids from the control group.

A significant difference was detected between the control and exposed group in the number of signals for major ribosomal genes (Mann-Whitney $\mathrm{U}, \mathrm{p}<0.001$, Fig $2 \mathrm{~b}$ ). The signal mode was 2 in both groups. However, a data distribution assessment showed the number of classes corresponding to the different signal numbers to increase in the group exposed to hydrogen peroxide. Interestingly, the percentage of cells displaying 1 and 2 signals was significantly lower (Fig 4).

The maximum number of detectable signals for major ribosomal genes on alkaline comets is eight when (i) the DNA amount of the cell is 4C and (ii) DNA is undamaged. As the maximum percentage of $4 \mathrm{C}$ we obtained was $4.6 \%$, the presence of more than four signals was considered as indicative of NOR fragmentation. Taking into account this percentage adjustment, $43.7 \%$ of the nulceoids exposed to hydrogen peroxide showed NOR fragmentation. This percentage was even higher when nucleoids with tails only were considered (54.9\%). 
In the group exposed to hydrogen peroxide, the DNA fragmentation level of NORs was significantly higher than in the controls (Pearson $X^{2}, \mathrm{p}<0.001$ ). Following exposure to the model genotoxicant, a positive correlation was also observed between the number of FISH signals and the percentage of DNA present in the comet tail (Spearman coefficient correlation of $0.70, \mathrm{p}<0.05)$.

\section{Discussion}

The simplicity, sensitivity, versatility, rapidity and low cost of the comet assay make it one of the most popular methods for assessing DNA damage, with applications in genotoxicology, human molecular epidemiology and the study of cell repair capacity (Collins, 2004). Nevertheless, despite its great versatility, the comet assay does not provide information on the nature and function of the damaged sequence. Its combination with the specificity of fluorescence in situ hybridisation allows us to analyse the effect of hydrogen peroxide on the structural integrity of nucleolar organizer regions in the hemocytes of the Pacific oyster Crassostrea gigas.

The presence of 1 to 4 major rDNA FISH signals in nucleoids coincides with cytogenetic data published for Crassostrea gigas. This species presents one NOR on the terminal region of the long arm of the metacentric chromosome pair 10 (Insua and Thiriot-Quiévreux, 1992; Xu et al., 2001). Therefore, the expected number of signals in undamaged nucleoids can range from 1 to 8 , depending on nuclear DNA content, cell cycle status and comet assay conditions, which promote the separation of DNA strands in alkaline conditions, hence doubling the number of FISH-signals. The duplication of FISH-signal numbers when applying the alkaline comet assay has already been described in animals and humans (Rapp et al., 2004), despite the fact that it does not occur systematically (Kwasniewska et al., 2012). In fact, comet heads are partially composed of renatured DNA, as previously suggested by acridine orange staining (Östling and Johanson, 1984) and FISH-detection of Cot-1 DNA in alkaline comet heads without previous denaturation (Shaposhnikov et al., 2008). Therefore, 2C cells corresponding to cells in $\mathrm{G}_{0} / \mathrm{G}_{1}$ phase are expected to display between 1 and 4 FISH-signals, whereas $4 \mathrm{C}$ cells corresponding to either cells in $\mathrm{G}_{2} / \mathrm{M}$ phase or polyploidy cells are expected to display no more than 8 signals. The majority of intact nucleoids from both the control and exposed groups showed 2 signals (61.64\% and $66.66 \%$, respectively) and no more than 4 FISH signals 
were detected, suggesting that most of the complementary denatured strands of DNA had renatured or stayed in close proximity, hence giving the same signal. A small percentage of 4C cells was detected by flow cytometry (4.6\%), which could partially explain the percentage of 4 FISH signals detected in intact nucleoids. In view of the relatively-low level of DNA damage measured by comet TD value, the extra FISH signals could be linked to the separation of DNA strands in alkaline conditions. Conversely, nucleolus organizer regions tend to aggregate during interphase forming the nucleoli (Kalmárová et al., 2007), explaining the presence of one and three signals detected in some nucleoids.

Although the comet tail is thought to be composed of single strand DNA in alkaline conditions, its formation remains poorly understood and various interpretations have been put forward. The electrophoretic behaviour and kinetic analysis of alkaline comets suggest that the tail mainly comprises fragments, whereas the nucleoid is a coil of single strand DNA molecules detached from the nuclear matrix due to the alkaline treatment (Afanasieva et al., 2010; Klaude et al., 1996). However, the persistence of some broken DNA sequences on alkaline comet heads contradicts this interpretation, suggesting that some damaged sequences may remain attached to the nuclear matrix (Horvathová et al. 2004). On the other hand, comet-FISH data suggests that single strand DNA, which comprises the alkaline comet tails, coalesces into a granular form (Shaposhnikov et al., 2008).

The aspect of FISH signals on comets reflected their chromatin topological organization. On alkaline comets with tail DNA, FISH signals were observed as clouds of dots over the comet head. Their appearance coincided with DNA organization into loops, which remained on the head despite the ability of the alkali treatment to detach DNA loops from the nuclear matrix (Afanasieva et al., 2010). This could be explained by the resistance of high molecular weight DNA to electrophoresis migration in agarose gels. The proximity of single strand DNA loops in comet heads can promote re-annealing during the neutralization process, explaining why the number of observed signals was generally 2 in the comet head and never 8. Given the tandem repeat organization of major ribosomal genes (Long and Dawid, 1980), FISH signals could be expected to be arranged in linear arrays on comets, as observed on fibre-FISH (Pérez-García et al., 2014). However, they appeared as individual and clouds of dots, supporting the idea that the single strand DNA constituting the alkaline comet tails had coalesced into a granular form (Shaponiskov et al., 2008). 
Hydrogen peroxide induced the fragmentation of NORs in exposed hemocytes. Although the number of major rDNA signals increased with the percentage of tail DNA, most of the comets (77.27\%) with NOR fragmentation showed FISH signals in the head, suggesting that some rDNA sequences or adjacent regions had remained attached to the nuclear matrix. Alternatively, the fragmented sequence may have been too long to migrate to the anode under electrophoretic field. Mammalian rRNA genes available for transcription have been previously reported as appearing to organize themselves into chromatin loops by tethering of non-transcribed inter-genic spacer region of the rDNA to the nuclear matrix. rDNA genes silenced by methylation are not recruited to the matrix (Shiue et al., 2014). Nevertheless, there is no evidence that the nuclear matrix is retained under alkaline treatment (Afanasieva et al., 2010).

Oxidative stress is known to be responsible for a rapid and reversible inhibition of protein synthesis via translation inhibition and oxidation of components of the translational apparatus and mRNA (Grant, 2011). Using comet-FISH, we observed NOR damage in the hemocytes of Crassostrea gigas exposed to hydrogen peroxide, hence pinpointing a possible negative effect on protein biosynthesis due to oxidative stress. Nucleolar organizer regions form nucleoli during the interphase rDNA; their instability may hence reduce rDNA transcription, resulting in lower ribosome biogenesis and affecting cellular functions (Kobayashi, 2008). However, rDNA copies that remain intact on comets could be transcribed anyway and fulfil cell requirements. In yeast, the number of copies of rDNA was shown to exceed the minimum number of genes required to obtain normal growth (French et al., 2003), with only half of copies transcribed. Despite the presence of NOR damage, the expression of major ribosomal genes could hence be maintained. Various evidence accumulated in recent years suggests that the nucleolus acts a sensitive sensor of genome damage and cellular stress (Hetman and Pietrzak, 2012; Shaw and Brown, 2012). In response to DNA damage, an ATM-dependent accumulation of the transcription factor E2F1 has already been described in the nucleolus; this mechanism plays a role in cell cycle arrest, DNA repair, apoptosis and the regulation of rDNA transcription (Jin et al., 2014). Conversely, nucleolus dysfunction has been shown to stabilize p53 preventing its degradation. As consequence, apoptosis, autophagy, cell cycle arrest, metabolic changes, and senescence may occur (Boyd et al., 2011; Elkholi and Chipuk, 2013). 
This study demonstrates the utility of the comet-FISH to analyse the fragmentation of NORs on hemocytes of Crassostrea gigas and reveals its potential use to analyse damaged induced by genotoxicant exposure in specific genes. However, despite of its efficacy in the assignment of DNA damage to genes and specific chromosomal regions (Mladinic et al., 2012; Reiter et al., 2012; Volpato et al., 2008, Hovhannisyan et al., 2005) and in the analysis of cellular DNA repair capacity (Guo et al., 2013; McKenna et al., 2012), this technique has not been widely employed in the field of ecotoxicology. This can be explained by the fact that its application, optimization and interpretation of the results require experience in gene mapping by FISH. In fact, the critical step of this method is to obtain proper probes for the gene of interest that do not generate background noise under low stringency conditions. In the other hand, a correct interpretation of the results require knowledge on the cell cycle phase, the DNA content $(\mathrm{C}$ value) and the number of chromosomal loci of the gene under study. This last data is not available for the majority of species, except for a little number of gene families, such as ribosomal genes and core histone genes. Nonetheless, the comet-FISH is a promising method in the field of genotoxicoloy and ecotoxicology, which can be used to study the sensitivity of target genes to genotoxicant exposure and cellular DNA repair capacity.

\section{Conclusions}

In this study, a comet-FISH assay was applied for the first time to bivalves following exposure to a model direct genotoxicant, allowing analysis of the structural integrity of NORs and hence the nucleoli of oyster hemocytes. Our data revealed NOR fragmentation, with possible severe consequences for cells. As bivalves are widely-used for monitoring environmental pollution in aquatic ecosystems, the application of comet-FISH to these organisms can provide additional and interesting information on the nature of the genomic regions affected by genotoxicant exposure and on cell repair capacity. Targeted probes can be used to better understand the consequences of genotoxicity on animal health, which remains poorly-documented in aquatic species. .

\section{Acknowledgments}

The authors wish to thank to Dr A. Benabdelmouna for kindly supplying the oysters and rDNA plasmid probe. This work was funded by the French National Research Agency (ANRCESA-01601). 


\section{Policy and ethics}

This work have been carried out in accordance with The Code of Ethics of the World Medical Association for animal experiments

\section{Conflict of interests}

The authors declare that they have no conflict of interests.

\section{Authors' contributions}

Pérez-García $\mathrm{C}$ developed and applied to the samples the comet-FISH protocol, reviewed the bibliography and collaborated in the writing of this paper. Rouxel $\mathrm{J}$ performed the flow cytometric techniques and helped in the developed of the laboratory techniques. Akcha $\mathrm{F}$ coordinated the study, helped in the comet and statistical analyses and coordinated the writing of the manuscript. All authors have read and approved the final manuscript. 
Fig 1: Flow cytometric analyses of nuclear DNA content of hemocytes reveal a small percentage of $4 \mathrm{C}$ hemocytes $(4.6 \%)$ in both the control (black line) and exposed group (red line).

Fig 2: Effect of $100 \mu \mathrm{M} \mathrm{H} \mathrm{H}_{2} \mathrm{O}_{2}$ exposure on levels of DNA fragmentation measured as tail DNA (a) and on the number of major rDNA signals registered on comets from oyster hemocytes (b).

Fig 3: FISH mapping of major ribosomal genes on mitotic metaphase chromosomes (a) and comets (b-i). Undamaged nucleoids (b-d) showed from 1 to 4 major rDNA signals. The number of signals present on the comets increased with DNA damage (e-i). Chromosomes and nucleoids were stained with propidium iodide.

Fig 4: Frequency distribution of FISH-signals in control and exposed groups. 


\section{References}

Afanasieva, K., Zazhytska, M., Sivolob, A., 2010. Kinetics of comet formation in single-cell gel electrophoresis: loops and fragments. Electrophoresis, 31(3), 512-519. doi:10.1002/elps.200900421

Akcha, F., Vincent Hubert, F., Pfhol-Leszkowicz, A., 2003. Potential value of the comet assay and DNA adduct measurement in dab (Limanda limanda) for assessment of in situ exposure to genotoxic compounds. Mutation Research, 534, 21-32. doi:10.1016/S13835718(02)00244-9

Asad, N. R., Oliverira Asad, L. M., Bonacossa de Almeida, C. E., Felzenszwalb, I., Cabralneto, J. B., Leitão, A. C., 2004. Several pathways of hydrogen peroxide action that damage the E. coli genome. Genetics and Molecular Biology, 27, 291-303. doi:10.1590/S1415-47572004000200026

Bachère, E., Gueguen, Y., Gonzalez, M., de Lorgeril, J., Garnier, J. and Romestand, B., 2004. Insights into the anti-microbial defense of marine invertebrates: the penaeid shrimps and the oyster Crassostrea gigas. Immunological Reviews, 198, 149-168. doi:10.1111/j.0105-2896.2004.00115.x

Boyd, M. T., Vlatkovic, N., Rubbi, C. P., 2011. The nucleolus directly regulates p53 export and degradation. The Journal of Cell Biology, 194(5), 689-703. doi: $10.1083 /$ jcb.201105143

Collins, A. R., 2004. The Comet Assay for DNA Damage and Repair. Molecular Biotechnology, 26, 249-262. doi:10.1385/MB:26:3:249

Cook, P. R., Brazell, I. A., 1976. Characterization of nuclear structures containing superhelical DNA. Journal of Cell Science, 22, 303-324

Dang, C., Lambert, C., Soudant, P., Delamare-Deboutteville, J., Zhang, M. M., Chan, J., Green, Timothy J., Le Goïc, NellyBarnes, A. C., 2011. Immune parameters of QXresistant and wild caught Saccostrea glomerata hemocytes in relation to Marteilia sydneyi infection. Fish and Shellfish Immunology, 31(6), 1034-1040. doi:10.1016/j.fsi.2011.09.003

Derijck, A. A. H. A., van der Heijden, G. W., Ramos, L., Giele, M., Kremer, J. A. M., de Boer, P., 2007. Motile human normozoospermic and oligozoospermic semen samples show a difference in double-strand DNA break incidence. Human Reproduction, 22(9), 2368-2376. doi:10.1093/humrep/dem166

Dixon, D. R., Pruski, A. M., Dixon, L. R. J., Jha, A. N., 2002. Marine invertebrate ecogenotoxicology: a methodological overview. Mutagenesis, 17(6), 495-507. doi: 10.1093/mutage/17.6.495

Elkholi, R., Chipuk, J. E. 2013. How do I kill thee? Let me count the ways: p53 regulates PARP-1 dependent necrosis. BioEssays, 36(1), 46-51. doi:10.1002/bies.201300117 
FAO 2002-2014. Global Aquaculture Production. Fishery Statistical Collections. FIGIS Data Collection. In: FAO Fisheries and Aquaculture Department [online]. Rome. Updated 4 September 2002. http://www.fao.org/fishery/aquaculture/en

French, S. L., Osheim, Y. N., Cioci, F., Nomura, M., Beyer, A. L., 2003. In exponentially growing Saccharomyces cerevisiae cells, rRNA synthesis is determined by the summed RNA polymerase I loading rate rather than by the number of active genes. Molecular and Cellular Biology, 23(5), 1558-1568. doi:10.1128/MCB.23.5.1558.2003

Glei, M., Schlörmann, W., 2014. Analysis of DNA damage and repair by comet fluorescence in situ hybridization (Comet-FISH). In J. C. Stockert, J. Espada, and A. Blázquez-Castro (Eds.), Functional Analysis of DNA and Chromatin. Humana Press, New York, pp. 3948. doi:10.1007/978-1-62703-706-8_4

González-Marín, C., Gosálvez, J., Roy, R., 2012. Types, causes, detection and repair of DNA fragmentation in animal and human sperm cells. International Journal of Molecular Sciences, 13(11), 14026-14052. doi:10.3390/ijms131114026

Grant, C. M., 2011. Regulation of translation by hydrogen peroxide. Antioxidants and Redox Signaling, 15(1), 191-203. doi:10.1089/ars.2010.3699

Guo, J., Hanawalt, P. C., Spivak, G., 2013. Comet-FISH with strand-specific probes reveals transcription-coupled repair of 8-oxoGuanine in human cells. Nucleic Acids Research, 41(16), 7700-7712. doi:10.1093/nar/gkt524

Hašplová, K., Hudecová, A., Magdolénová, Z., Bjøras, M., Gálová, E., Miadoková, E., Dušinská, M., 2012. DNA alkylation lesions and their repair in human cells: modification of the comet assay with 3-methyladenine DNA glycosylase (AlkD). Toxicology Letters, 208(1), 76-81. doi:10.1016/j.toxlet.2011.10.005

Hernandez-Verdun, D., 2006. Nucleolus: from structure to dynamics. Histochemistry and Cell Biology, 125(1-2), 127-137. doi:10.1007/s00418-005-0046-4

Hetman, M., Pietrzak, M., 2012. Emerging roles of the neuronal nucleolus. Trends in Neurosciences, 35(5), 305-314. doi:10.1016/j.tins.2012.01.002

Horvathová, E., Dusinká, M., Shaposhnikov, S., Collins, A. R., 2004. DNA damage and repair measured in different genomic regions using the comet assay with fluorescent in situ hybridization. Mutagenesis, 19(4), 269-276. doi:10.1093/mutage/geh030

Hovhannisyan, G., Rapp, A., Arutyunyan, R., Greulich, K. O., Gebhart, E., 2005. Cometassay in combination with PNA-FISH detects mutagen-induced DNA damage and specific repeat sequences in the damaged DNA of transformed cells. International Journal of Molecular Medicine, 15(3), 437-442. doi:10.3892/ijmm.15.3.437

Insua, A., Thiriot-Quiévreux, C., 1992. Nucleolar organiser region variation in the chromosomes of three oyster species. Journal of Experimental Marine Biology and Ecology, 157(1), 33-40. doi:10.1016/0022-0981(92)90072-I 
Jin, Y. Q., An, G. S., Ni, J. H., Li, S. Y., Jia, H. T., 2014. ATM-dependent E2F1 accumulation in the nucleolus is an indicator of ribosomal stress in early response to DNA damage. Cell Cycle, 13(10), 1627-1638. doi:10.4161/cc.28605

Kalmárová, M., Smirnov, E., Masata, M., Koberna, K., Ligasová, A., Popov, A., Raska, I., 2007. Positioning of NORs and NOR-bearing chromosomes in relation to nucleoli. Journal of Structural Biology, 160(1), 49-56. doi:10.1016/j.jsb.2007.06.012

Klaude, M., Eriksson, S., Nygren, J., Ahnström, G., 1996. The comet assay: mechanisms and technical considerations. Mutation Research, 363(2), 89-96. doi:10.1016/09218777(95)00063-1

Kobayashi, T., 2008. A new role of the rDNA and nucleolus in the nucleus-rDNA instability maintains genome integrity. BioEssays, 30(3), 267-272. doi:10.1002/bies.20723

Kushwaha, S., Vikram, A, Trivedi, P. P., Jena, G. B., 2011. Alkaline, Endo III and FPG modified comet assay as biomarkers for the detection of oxidative DNA damage in rats with experimentally induced diabetes. Mutation Research, 726(2), 242-250. doi:10.1016/j.mrgentox.2011.10.004

Kwasniewska, J., Grabowska, M., Kwasniewski, M., Kolano, B., 2012. Comet-FISH with rDNA probes for the analysis of mutagen-induced DNA damage in plant cells. Environmental and Molecular Mutagenesis, 53(5), 369-375. doi:10.1002/em.21699

Long, E. O., Dawid, I. B., 1980. Repeated genes in eukaryotes. Annual Review of Biochemistry, 49, 727-764. doi:10.1146/annurev.bi.49.070180.003455

Lopez-Barea, J., Pueyo, C., 1998. Mutagen content and metabolic activation of promutagens by molluscs as biomarkers of marine pollution. Mutation Research, 399, 3-15. doi:10.1016/S0027-5107(97)00262-5

Magnander, K., Elmroth, K., 2012. Biological consequences of formation and repair of complex DNA damage. Cancer Letters, 327(1-2), 90-96. doi:10.1016/j.canlet.2012.02.013

Martínez-Expósito, M., Pasantes, J. J., Méndez, J., 1994. Proliferation kinetics of mussel (Mytilus galloprovincialis) gill cells. Marine Biology, 120(1), 41-45. doi:10.1007/BF00381940

McKenna, D. J., Doherty, B. A., Downes, C. S., McKeown, S. R., McKelvey-Martin, V. J., 2012. Use of the comet-FISH assay to compare DNA damage and repair in p53 and hTERT genes following ionizing radiation. Plos One, 7(11), e49364. doi:10.1371/journal.pone.0049364

Mermershtain, I., Glover, J. N. M., 2013. Structural mechanisms underlying signaling in the cellular response to DNA double strand breaks. Mutation Research, 750(1-2), 15-22. doi:10.1016/j.mrfmmm.2013.07.004 
Meunier-Rotival, M., Cortadas, J., Macaya, G.; Bernardi, G., 1979. Isolation and organization of calf ribosomal DNA. Nucleic Acids Research, 6(6), 2109-2123. doi: 10.1093/nar/6.6.2109

Mladinic, M., Zeljezic, D., Shaposhnikov, S. A., Collins, A. R., 2012. The use of FISH-comet to detect c-Myc and TP 53 damage in extended-term lymphocyte cultures treated with terbuthylazine and carbofuran. Toxicology Letters, 211(1), 62-69. doi:10.1016/j.toxlet.2012.03.001

Ostling, O., Johanson, K., 1984. Microelectrophoretic study of radiation-induced DNA damages in individual mammalian cells. Biochemical and Biophysical Research Communications, 123(1), 291-298. doi:10.1016/0006-291X(84)90411-X

Pérez-García, C., Hurtado, N. S., Morán, P., Pasantes, J. J., 2014. Evolutionary dynamics of rDNA Clusters in chromosomes of five clam species belonging to the family Veneridae (Mollusca, Bivalvia). BioMed Research International, 2014, 1-9. doi:10.1155/2014/754012

Rapp, A., Hausmann, M., Greulich, K. O., 2004. The Comet-FISH Technique: A Tool for Detection of Specific DNA Damage and Repair. In P. Keohavong and S. G. Grant (Eds.), Molecular Toxicology Protocols. Humana Press, pp. 107-119. doi:10.1385/1-59259840-4:107

Reiter, M., Baumeister, P., Boeck, D., Schwenk-Zieger, S., Harréus, U., 2012. Reduction of DNA damage by curcumin and celecoxib in epithelial cell cultures of the oropharynx after incubation with tobacco smoke condensate. Anticancer Research, 32 (8): 31853189.

Robert, R., Gerard, A., 1999. Bivalve hatchery technology: The current situation for the Pacific oyster Crassostrea gigas and the scallop Pecten maximus in France. Aquatic Living Resources, 12(2), 121-130. doi:10.1016/S0990-7440(99)80021-7

Roos, W. P., Kaina, B., 2013. DNA damage-induced cell death: from specific DNA lesions to the DNA damage response and apoptosis. Cancer Letters, 332(2), 237-248. doi:10.1016/j.canlet.2012.01.007

Samain, J. F., 2011. Review and perspectives of physiological mechanisms underlying genetically-based resistance of the Pacific oyster Crassostrea gigas to summer mortality. Aquatic Living Resources, 24, 227-236. doi:10.1051/alr/2011144

Santos, R., Palos-Ladeiro, M., Besnard, A, Reggio, J., Vulliet, E., Porcher, J. M., Bony, S., Sanchez, W., Devaux, A., 2013. Parental exposure to methyl methane sulfonate of threespined stickleback: contribution of DNA damage in male and female germ cells to further development impairment in progeny. Ecotoxicology, 22(5), 815-824. doi:10.1007/s10646-013-1088-3

Santos, S. J., Singh, N. P., Natarajan, A. T., 1997. Fluorescence in Situ Hybridization with Comets. Experimental Cell Research, 411(232), 407-411. 
Shaposhnikov, S. A., Salenko, V. B., Brunborg, G., Nygren, J., Collins, A. R., 2008. Singlecell gel electrophoresis (the comet assay): loops or fragments? Electrophoresis, 29(14), 3005-3012. doi:10.1002/elps.200700921

Shaposhnikov, S., Frengen, E., Collins, A. R., 2009. Increasing the resolution of the comet assay using fluorescent in situ hybridization-a review. Mutagenesis, 24(5), 383-389. doi:10.1093/mutage/gep021

Shaw, P., Brown, J., 2012. Nucleoli: composition, function, and dynamics. Plant Physiology, 158(1), 44-51. doi:10.1104/pp.111.188052

Shiue, C.-N., Nematollahi-Mahani, A., Wright, A. P. H., 2014. Myc-induced anchorage of the rDNA IGS region to nucleolar matrix modulates growth-stimulated changes in higherorder rDNA architecture. Nucleic Acids Research, 42(9), 5505-5517. doi:10.1093/nar/gku183

Simoes, R., Feitosa, W. B., Siqueira, A. F., Nichi, M., Paula-Lopes, F. F., Marques, M. G. Peres, M. A., Barnabe, V. H., Visintin, J. A., Assumpção, M. E., 2013. Influence of bovine sperm DNA fragmentation and oxidative stress on early embryo in vitro development outcome. Reproduction, 146, 433-441. doi:10.1530/REP-13-0123

Volpato, C. B., Martínez-Alfaro, M., Corvi, R., Gabus, C., Sauvaigo, S., Ferrari, P., Bonora, E., de Grandi, A., Romeo, G., 2008. Enhanced sensitivity of the RET proto-oncogene to ionizing radiation in vitro. Cancer Research, 68(21), 8986-8992. doi:10.1158/00085472.CAN-08-1032

Waykar, B., Deshmukh, G., 2012. Evaluation of bivalves as bioindicators of metal pollution in freshwater. Bulletin of Environmental Contamination and Toxicology, 88, 48-53. doi:10.1007/s00128-011-0447-0

Xu, Z., Guo, X., Gaffney, P., Pierce, J., 2001. Chromosomal location of the major ribosomal RNA genes in Crassostrea virginica and Crassostrea gigas. The Veliger, 44(1), 79-83. 


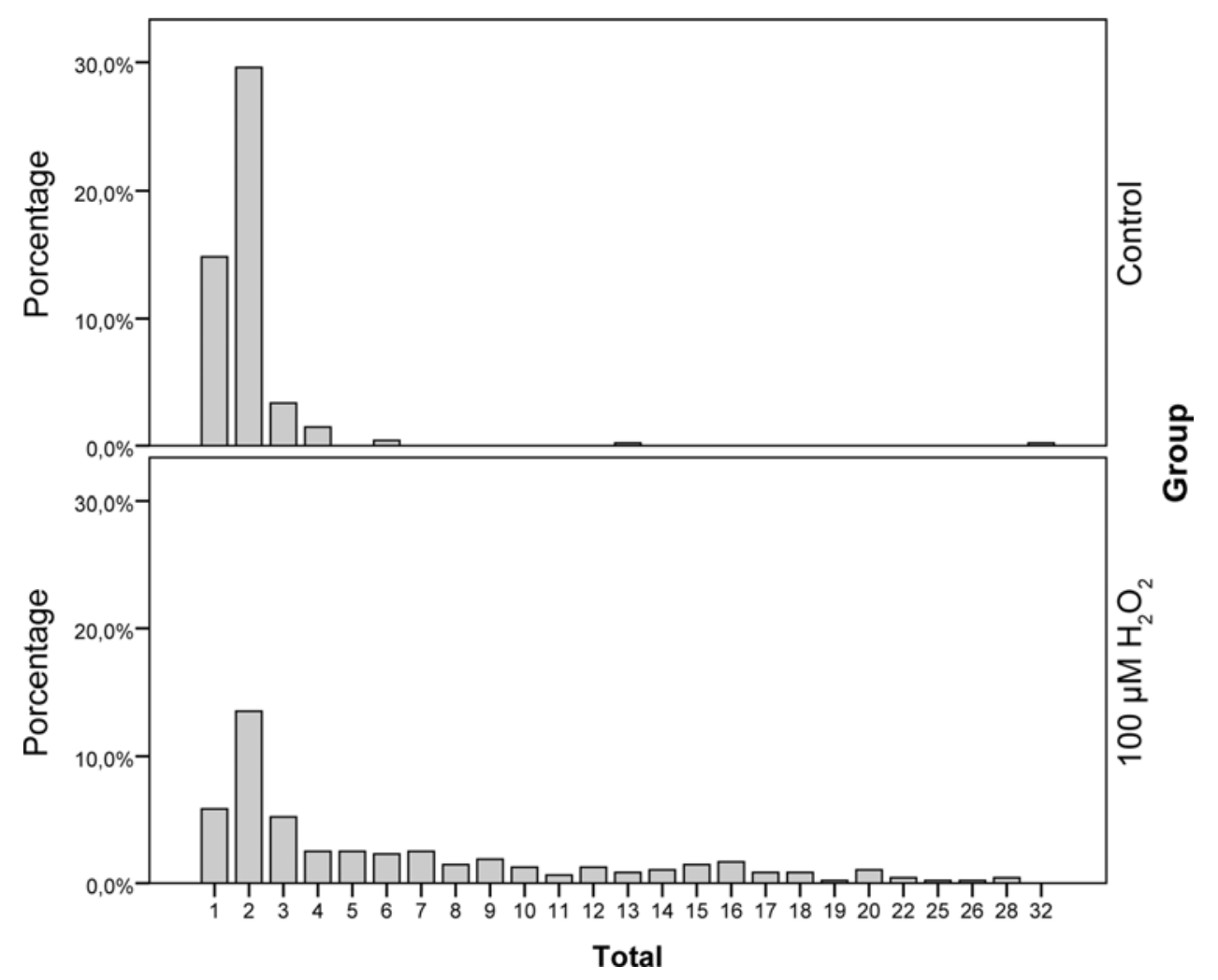

Fig. 4 


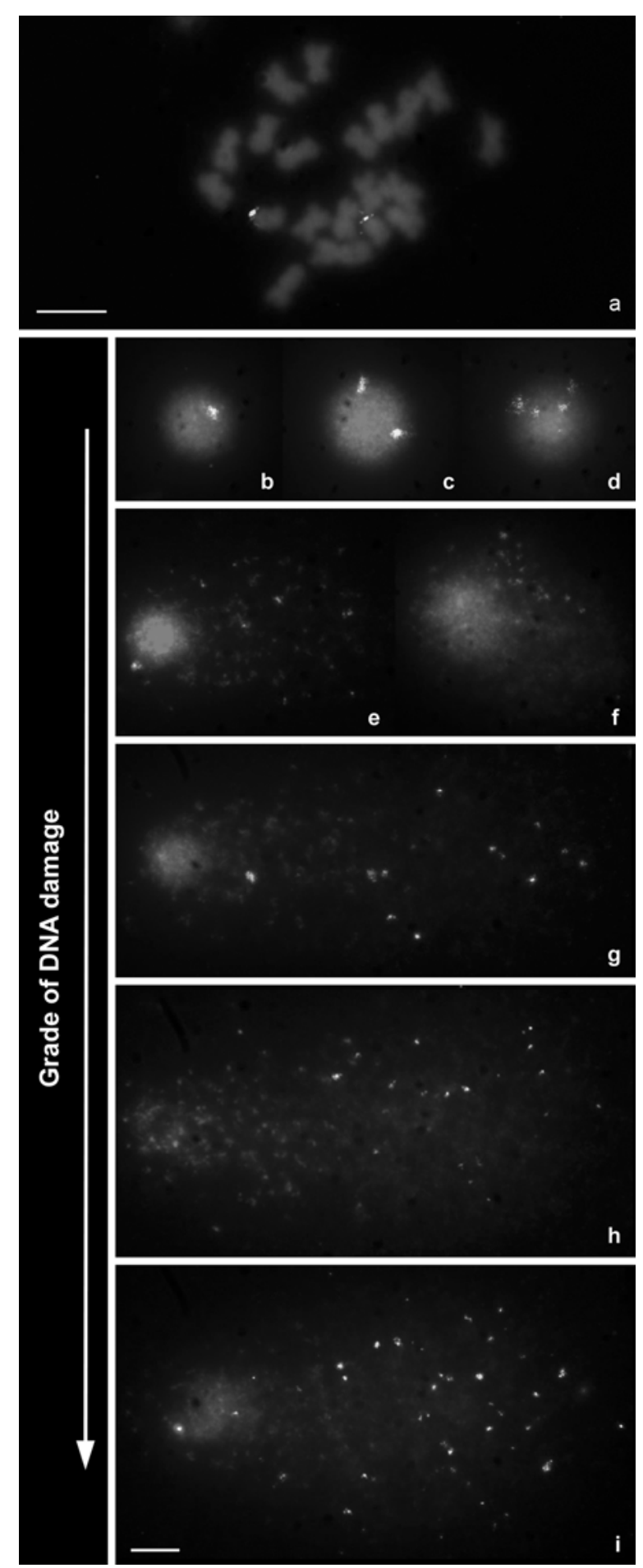

Fig. 3 

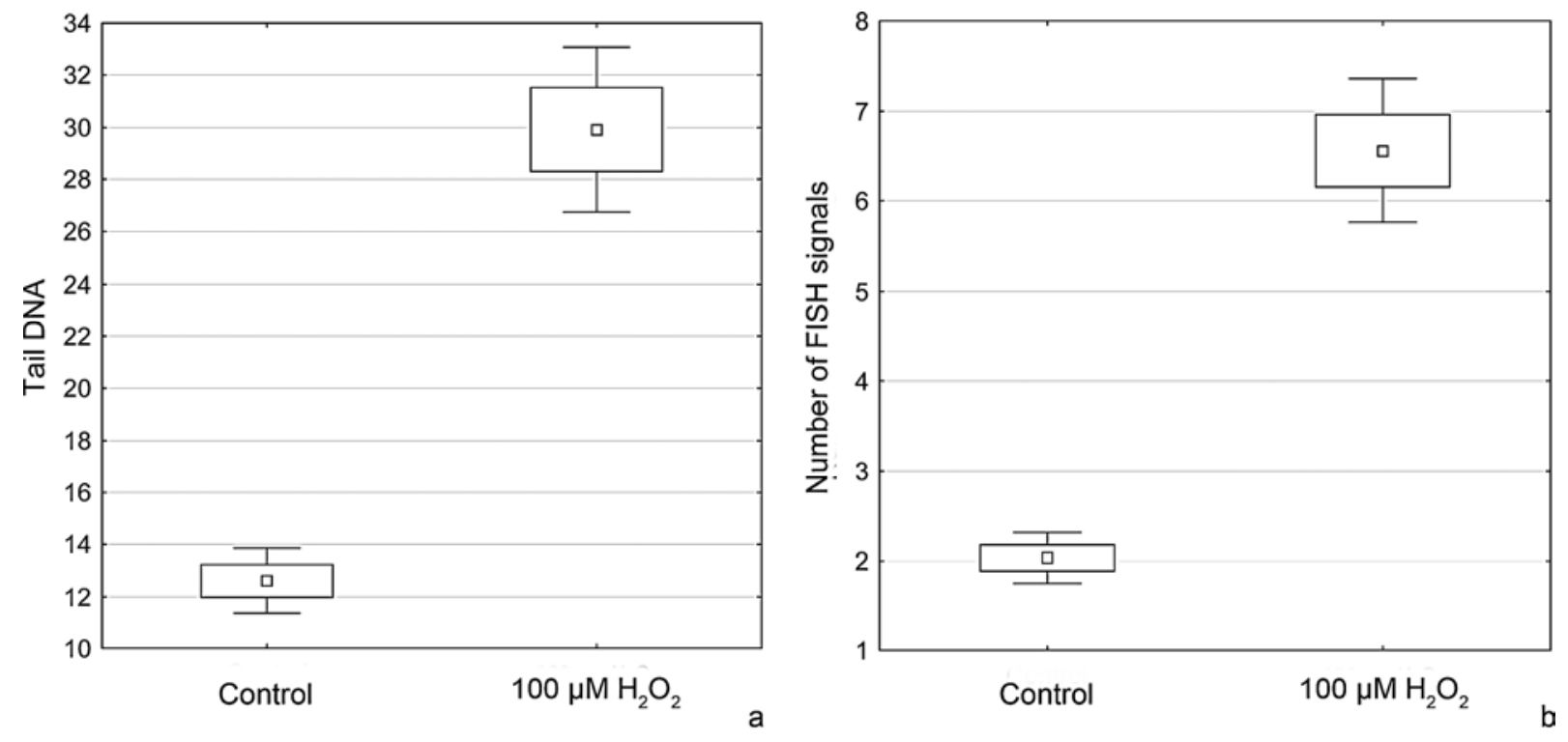

- Mean $\square$ Mean \pm SE I Mean $\pm 0,95$ Conf. Interval

Fig. 2

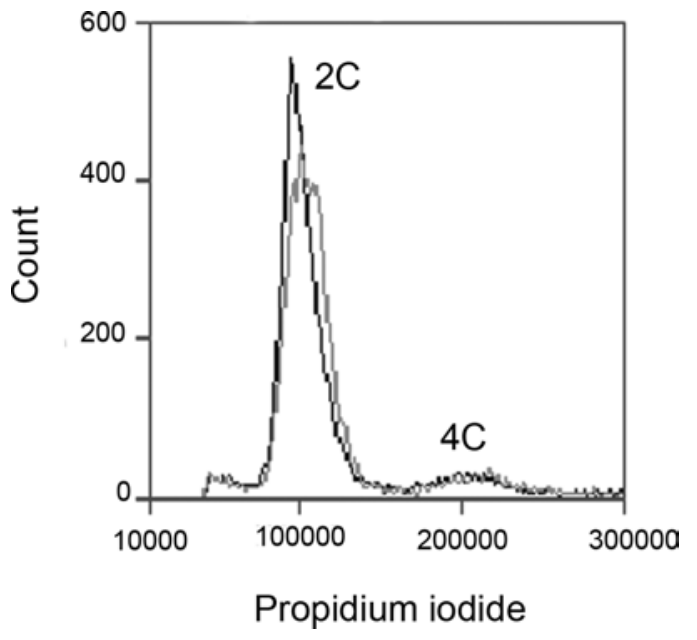

Fig. 1 